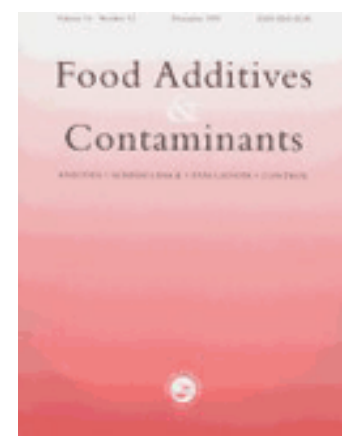

\title{
Assessment of the exposure to Allura red colour from the consumption of red juice-based and red soft drinks in Italy
}

\begin{tabular}{|c|c|}
\hline Journal: & Food Additives and Contaminants \\
\hline Manuscript ID: & TFAC-2011-139.R1 \\
\hline Manuscript Type: & Original Research Paper \\
\hline $\begin{array}{r}\text { Date Submitted by the } \\
\text { Author: }\end{array}$ & 06-Jun-2011 \\
\hline Complete List of Authors: & $\begin{array}{l}\text { Fallico, Biagio; Università di Catania, GESA } \\
\text { Chiappara, Elena; Università di Catania, GESA } \\
\text { Elena, Arena; Università di Catania, GESA } \\
\text { Gabriele, Ballistreri; Università di Catania, GESA }\end{array}$ \\
\hline Methods/Techniques: & $\begin{array}{l}\text { Chromatography - HPLC, Exposure - prob modelling, Exposure } \\
\text { assessment }\end{array}$ \\
\hline Additives/Contaminants: & Colours \\
\hline Food Types: & Beverages, Fruit juices \\
\hline Abstract: & $\begin{array}{l}\text { This paper reports on a survey and an exposure study, based on a } \\
\text { probabilistic approach, concerning red juice-based and red soft } \\
\text { drink products in Italy. This study highlighted that the estimations, } \\
\text { both of consumption rates and colorant intakes, are related to the } \\
\text { hypotheses of scenarios. In fact, the study estimated that, on the } \\
\text { average, consumers of red soft drinks consume } 53.1 \text { litres per year, } \\
\text { ranging from } 39.1 \text { litres to } 70.7 \text { litres of soft drink products under a } \\
\text { scenario, or, } 21.3 \text { litres, ranging from } 12.7 \text { litres and } 35.9 \text { litres } \\
\text { under other hypotheses; while } 9.5 \text { litres of red juice-based drinks } \\
\text { are consumed per year, ranging between } 7.0 \text { litres and } 12.5 \text { litres, } \\
\text { under a scenario, or, on the average, } 6.9 \text { litres, ranging from } 3.2 \\
\text { litres and } 17.7 \text { litres, under the other scenario. } \\
\text { The amount of colorant in a red beverage ranges from } 10.9 \mathrm{mg} / \mathrm{l} \text { in } \\
\text { a red soft drink up to } 55.9 \mathrm{mg} / \mathrm{l} \text { in a red-juice based product. The } \\
\text { risk evaluation process showed that in all cases, the intake of E129 } \\
\text { was always lower than the Acceptable Daily Intake value. The } \\
\text { exposure assessment showed high average intakes of Allura red in }\end{array}$ \\
\hline
\end{tabular}




\section{SCHOLARONE Manuscripts}

the worst-case scenario, on the average, $6.5 \mathrm{mg} /$ day and 13.9 $\mathrm{mg} /$ day, up to $25.0 \mathrm{mg} /$ day and $33.0 \mathrm{mg} /$ day at the 95th percentile, from juice-based and soft drinks respectively. The most realistic scenario estimated a weighted average daily intake of Allura red, on the average about $0.3 \mathrm{mg} /$ day up to $0.5 \mathrm{mg} /$ day at the 95th percentile, and $0.4 \mathrm{mg} /$ day up to $0.6 \mathrm{mg} /$ day at the 95th percentile, from juice-based and soft drinks, respectively. Actually, the highest colorant intake was estimated in a "health" juice-based drink. The intake of E129 significantly increased with a high level of colorant (> $40 \mathrm{mg} / \mathrm{l})$. 


\section{Assessment of the exposure to Allura red colour from the consumption of}

2 red juice-based and red soft drinks in Italy

3

4 B. Fallico*, E. Chiappara, E. Arena, G. Ballistreri

5 Dipartimento GeSA, Università degli Studi di Catania, Italy

6

7 *Email: bfallico@ unict.it, Tel. 0039957580214.

9 Abstract

10 This paper reports the results of a survey and an exposure study, based on a probabilistic 11 approach, concerning red juice-based and red soft drink products in Italy. This study 12 highlighted that the estimates, both of consumption rates and colourant intakes, are related to 13 the hypotheses of scenarios. In fact, the study estimated that, on average, consumers of red 14 soft drinks consume 53.1 litres per year, ranging from 39.1 litres to 70.7 litres of soft drink 15 products under one scenario, or, 21.3 litres, ranging from 12.7 litres and 35.9 litres under 16 another hypotheses; while 9.5 litres of red juice-based drinks are consumed per year, ranging 17 between 7.0 litres and 12.5 litres, under one scenario, or, on the average, 6.9 litres, ranging 18 from 3.2 litres and 17.7 litres, under another scenario. The amount of colourant in a red 19 beverage ranged from $10.9 \mathrm{mg} / \mathrm{l}$ in a red soft drink up to $55.9 \mathrm{mg} / \mathrm{l}$ in a red-juice based 20 product. The risk evaluation process showed that in all cases, the intake of E129 was always 21 lower than the Acceptable Daily Intake value. The exposure assessment showed high average 22 intakes of Allura red in the worst-case scenario, on average, $6.5 \mathrm{mg} /$ day and $13.9 \mathrm{mg} /$ day, up 23 to $25.0 \mathrm{mg} / \mathrm{day}$ and $33.0 \mathrm{mg} / \mathrm{day}$ at the $95^{\text {th }}$ percentile, for juice-based and soft drinks 24 respectively. The most realistic scenario estimated a weighted average daily intake of Allura 25 red, on average about $0.3 \mathrm{mg} / \mathrm{day}$ up to $0.5 \mathrm{mg} / \mathrm{day}$ at the $95^{\text {th }}$ percentile, and $0.4 \mathrm{mg} / \mathrm{day}$ up to 
$10.6 \mathrm{mg} / \mathrm{day}$ for the $95^{\text {th }}$ percentile, from juice-based and soft drinks, respectively. Actually, the 2 highest colorant intake was estimated in a "health" juice-based drink. The intake of E129 3 significantly increased with a high level of colorant (> $40 \mathrm{mg} / \mathrm{l})$.

Keywords: Allura red, beverages, risk analysis, EDI, ADI, probabilistic approach, @ risk.

\section{Introduction}

8 Food colourants, both naturally derived and synthetic, are widely used by the food industry.

9 Allura red (2-hydroxy-1-(2-methoxy, 5-methyl, 4-sulphonatophenylazo)-naphthalene-610 sulphonate) disodium salt, also known as EU additive 129 (E129) or FD\&C Red No. 40 11 (USA), is one of the most widely used synthetic diazo colourants. Directive 94/36/EC on 12 colours for use in foodstuffs fixes a limit of $100 \mathrm{mg} / \mathrm{l}$ for E129 in non-alcoholic flavoured 13 drinks. Safety aspects have been assessed and reported by the Joint FAO/WHO Expert 14 Committee on Food Additives (JECFA, 1974, 1980, 1981), as well as by the EU Scientific 15 Committee for Food (SCF, 1975, 1984, 1989). Both Committees have established an 16 acceptable daily intake (ADI) of $0-7 \mathrm{mg} / \mathrm{kg}$ of body weight/day ( $\mathrm{mg} / \mathrm{kg} \mathrm{bw} /$ day). The studies 17 on which the JECFA and SCF assessments were based showed a very low acute toxicity of 18 Allura red as measured in different species of animals (LD50: 10,000 mg/kg bw for rats and 19 rabbits and $5000 \mathrm{mg} / \mathrm{kg}$ bw for dogs (Weir, 1965a, 1965b, 1967). Recently, Sasaki et al. 20 (2002) tested 39 food additives and defined a LD50 for Allura red of $>2000 \mathrm{mg} / \mathrm{kg}$. Studies 21 on sub-chronic and chronic toxicity, as well on carcinogenity (Serota et al., 1977; Borzelleca 22 et al. 1989, 1991), showed that the incidence of tumours or lesions in control and treated 23 animals were very similar. Details concerning the safety aspects of Allura Red can be found 24 in the JECFA $(1980,1981)$ and WHO reports (2009), respectively.

25 However, after the publication of the book Why your Child is Hyperactive? (Feingold, 
1 1975), concerning the role of synthetic colourants on children's behaviour (attention deficit

2 disorder (ADD) and/or attention deficit hyperactivity disorder (ADHD)), their use has been

3 widely debated. Vorhees et al. (1983) showed that Allura red in the diet significantly reduced

4 reproductive success and organ development, and that it modified the behaviour of young

5 rats, although it was not possible to confirm the Feingold hypothesis. Generally speaking,

6 there is a strong feeling that a gap in the data exists regarding the assessment of exposure of

7 infants and children to Allura red. Often, specific toxicity tests are asked to include data on

8 the relative sensitivity of this sub-population (Reed, 1997). Studies concerning different age

9 susceptibilities to carcinogenesis (Hattis et al., 2004), as well as studies on paediatric

10 pharmacokinetics (Ginsberg et al., 2004), have been carried out. Recently, in vivo Comet

11 studies (Tsuda et al., 2001; Sasaki et al., 2002) excluded a general toxicity of Allura red, but

12 highlighted specific DNA damage in the colon and in the stomach at the very low Allura red

13 levels of $10 \mathrm{mg} / \mathrm{kg}$ and $100 \mathrm{mg} / \mathrm{kg}$, respectively. Moreover, a new study reported that 14 exposure to two mixtures of four synthetic colours (mixture A: E102, E124, E110, E122; 15 mixture B: E110, E122, E104, E129) plus a sodium benzoate preservative in the diet resulted 16 in increased hyperactivity in 3-year-old and 8-9-year-old children in the general population 17 (McCann et al., 2007). The colours, and generally the additives, may have not only the above 18 mentioned effects, but can increase intolerance and allergy in children (Bourrier, 2006). Other 19 studies have been carried out to assess the daily intake of some food colourants in several 20 foodstuffs and non-alcoholic beverages. One study designed a screening method to identity 21 food colourants used in non-alcoholic beverages, which could potentially be consumed at 22 levels exceeding the ADIs, by using a tiered approach (Tennant 2008). Other studies 23 concluded that children were exposed to levels of some food colourants, which exceeded the 24 ADIs (Rao et al., 2004; Husain et al., 2006).

25 European Parliament and Council Directives 94/35/EC, 94/36/EC and 95/2/EC require 
1 each Member State to monitor the consumption and usage of food additives (Report EU, 2 2001). The European Food Safety Authority (EFSA), specifically the Panel on Food

3 Additives, Flavourings, Processing Aids and Food Contact materials, following a request

4 from the European Commission, was asked to assess the results of the McCann study and it

5 was concluded that this study provided limited evidence that the two different mixtures tested

6 had a small and statistically significant effect on activity and attention in the selected children,

7 and that the clinical significance of the observed effects remains unclear. Therefore, the panel

8 concluded that the results of the McCann study cannot be used as the basis for altering the

9 ADIs of the respective food colourants or sodium benzoate (EFSA, 2008, 2009).

Recently, in order to harmonise the use of food additives in foods in the community,

11 the European Parliament and the Council of the European Union adopted Regulation (EC)

12 No. 128/2008 of 22th December 2008 on food additives. This regulation defines 'colours' as

13 substances that add or restore colour in a food, and include natural constituents of foods and

14 natural sources which are normally not consumed as foods as such and not normally used as

15 characteristic ingredients of food. Preparations obtained from foods and other edible natural 16 source materials obtained by physical and/or chemical extraction resulting in a selective 17 extraction of the pigments relative to the nutritive or aromatic constituents are colours within 18 the meaning of the Regulation'.

19 Despite this scientific advice, since July 2010, Annex V of Regulation (EC) No. $201333 / 2008$ provides a list of food colours (E 110, E 104, E 122, E 129, E 102, E 124) which 21 must be included on food labels with the following information: 'may have an adverse effect 22 on activity and attention in children'.

23 Over the last few years, after a period where $100 \%$ juices seemed to be very popular 24 and widespread, the market showed a slowdown in sales of these products and a significant 25 increase in sales of fruit juice-based drinks (Rossi, 2006; Muraca, 2007). These beverages 
1 allowed both a product innovation and, overall, a significant reduction of fruit and, as a

2 consequence, a reduction in costs (Rossi, 2006). The beverages sector is one of the most

3 important food areas where Allura red is widely used, mainly in fruit-based drinks and soft

4 drinks based on red fruit juices The success of these beverages comes from the increasing

5 consumer demand for foods containing anthocyanins due to their health properties (Mazza,

6 2007; Bitsch et al., 2004; Galvano et al., 2004; Bonina et al., 2005). Many foods are important

7 sources of anthocyanins (Wu et al., 2006), but in Italy these are immediately associated with

8 red (blood) oranges (Maccarone et al., 1983, 1985). The chemical composition (Fallico et al.,

9 1996; Arena et al., 1998; Maccarone et al., 1998; Rapisarda et al., 1998; Arena et al., 2006),

10 the influence of processing (Arena et al., 2000; Arena et al., 2001a; Arena et al., 2001b), the

11 recovery of valuable products (Di Mauro et al., 2000; Di Mauro et al., 2002) and the safety

12 aspects (Fallico et al., 2009) of red oranges have been thoroughly investigated.

13 Risk assessment is based on a deterministic approach, when the calculated risk is 14 based on a point estimate, or on a probabilistic approach, where both the variability and 15 uncertainty of input variables are taken into consideration by using probability distributions to 16 represent the input variables instead of point estimates (Vose, 2000; Spanjersberg et al., 17 2007). The probabilistic approach was used by Slob and Pieters (1998) to estimate acceptable 18 human exposure limits (RfD, ADI, TDI) by using distributions of extrapolation factors instead 19 of single uncertainty factors, which are more conservative. Besides this, Slob (2006) 20 published a study on probabilistic dietary exposure assessments, taking into account the 21 variability in both amount and frequency of consumption. The probabilistic model was also 22 used (Spanjesberg et al., 2007) for allergen risk assessment, resulting in a more exhaustive 23 risk assessment than traditional deterministic risk assessments.

24 This paper reports the results of a research project, which investigated the 25 characteristics of red beverages, both juice-based and soft drinks, in Italy. In particular, the 
1 intake and exposure of the Italian population to Allura red from these beverages was

2 estimated. This assessment was carried out using different modelling intakes.

\section{Materials and methods}

\section{$4 \quad$ Sampling and chemical analysis}

\section{$5 \quad H P L C$ analyses of colourants}

6 Sample $(10 \mathrm{ml})$ was appropriately diluted with water and filtered through a $0.45 \mu \mathrm{m}$ (Albet).

7 HPLC analyses were conducted on a Shimadzu ClassVP LC-10ADvp equipped with a SPD-

8 M10Avp diode array detector. The column was a C18 Omnispher (Varian) $(150 \mathrm{~mm} \times 4.6$

$9 \mathrm{~mm}, 5 \mu \mathrm{m})$ and the chromatographic conditions were in agreement with those of Minioti et al.

10 (2007). Each colourant was identified by comparing the retention time, splitting the peak of

11 colours detected in the sample with the colour standard, and comparing the UV-vis spectra of

12 the colour standards with those of the samples. The amount of each colour was determined

13 using an external calibration curve, measuring the signal at $504 \mathrm{~nm}$ for E129, $485 \mathrm{~nm}$ for 14 E110 and $516 \mathrm{~nm}$ for E122. The purity of the colours was evaluated according to Minioti et 15 al. (2007) and Dir CE 2008/128: they were 88.1\% for E129, 88.7\% for E110 and 86.9\% for 16 E122. Details (uncertainty, limits of detection and precision) of the HPLC method are 17 reported in Fallico et al. (2010).

\section{Estimation of the consumption of red beverages}

19 For the first two scenarios the consumers characteristics (age, weight), the food categories and 20 the daily consumption rates of juice-based and soft drinks were those reported in INRAN21 SCAI 2005-06 survey (Leclercq et al. 2009). For all others the estimates of yearly and daily 22 consumption, as well as the number of consumers, of total red beverages, red fruit juice-based 23 and red soft drinks, were made using yearly sales data of the 27 selected shops. Personal 
1 communication with the managers of the shopping chain was essential in order to obtain both

2 sets of data.

\section{Risk assessment}

4 The estimated daily intake (EDI) of Allura red was made by following the methods described 5 in Petersen and Barraj (1996) and Douglass and Tennant (1997). A tired approach was used to 6 estimate the exposure with different scenarios. Details of each scenario are reported in table 1. 7 First, a MPL (Maximum Permitted Level) (EFSA, 2009) than a SPM (Single Point Method)

8 (Petersen and Barraj, 1996), were hypothised. After, as to our knowledge no specific data, 9 both for consumption and for colorant levels, in Italian red fruit based beverages were 10 available, more refined scenarios were attempt. This part of the study was carried out with the 11 collaboration of the Roberto Abate spa company, which owns a chain of more than 40 shops, 12 each having from 200 to $6000 \mathrm{~m}^{2}$ of selling area. It represents about the $10 \%$ of food retailers 13 in the metropolitan area of Catania (Italy) ( 1.0-1.5 million people). One year selling data 14 from 27 shops, including all of the largest ones, were used for this study. Moreover, from 15 these shops, all of the red fruit juice-based and red soft drinks were sampled in triplicate, 16 excluding $100 \%$ juices. A total of seventeen different brands were collected. For these 17 scenarios (3A, 3B and 4) a probabilistic approach was used. The distribution of the colour 18 concentration $(\mathrm{mg} / \mathrm{kg})$ in non-alcoholic beverages was multiplied with the distribution of 19 beverages. In order to carry out a safety evaluation of colourant E129 exposure, a risk 20 assessment model with a probabilistic approach from @ Risk software ver.5.5 was used 21 (Palisade Inc., Newfield, NY, USA). In this kind of analysis the single values are replaced 22 from distributions of probability; a value selected at random from the food consumption 23 distribution curve was multiplied by a value drawn at random from the colour concentration 24 distribution curve; this process was repeated thousands of times until the pre-planned number 
1 of repetitions was reached.

\section{Simulations}

3 Simulations were run in order to obtain estimations of the following parameters: the number

4 of customers (total, red beverages, red soft drinks and red juice-based drinks (Table 4); the

5 distribution of red beverage consumption for consumers only (Table 5); yearly and daily

6 intakes (mg) of E129 for each beverage (Tables 6-8). The conditions of each simulation were

7 as follows: number of iterations: 10,000; sampling type: Latin hypercube. For each simulation

8 output the probability distribution between the $5^{\text {th }}$ and $95^{\text {th }}$ percentiles, the mean, the standard

9 deviation and the uncertainty parameters were recorded. Moreover the best fitting

10 distribution, according to the K-S value, was extrapolated.

\section{Results and discussion}

12 The estimation of daily intake of a substance from a food source needs data concerning the

13 amount of food eaten and the level at which the compound is present in that food. Many

14 methods can be used to obtain these data; the most common refer to the literature and specific

15 surveys of food intake (Douglass and Tennant, 1997). Data concerning the consumption of 16 juices, nectars and soft drinks in Italy in 2009 indicates a consumption of 66 litres per year per

17 capita for carbonated, still and sports/energy drinks and of 15 litres per year per capita for 18 pure juices, nectars and juice-based drinks (Bevitalia, 2010 a,b). However, to the best of our 19 knowledge, specific data concerning the red beverages sector do not exist.

20 The sales data of the selected 27 shops over a one-year period, covering a total area 21 with 1-1.5 million people, are reported in Table 2. In one year 5,100,630 receipts were given 22 out and 49,856 red beverages were sold with a total of $62,682.8$ litres. In particular, the red 23 juice-based drinks accounted for 32,640.8 litres and the red soft drinks for 30,042 litres. 
1 Furthermore, from the collected data it was possible to establish that red juice-based drinks

2 represented about $5.7 \%$ of all juice-based drinks, while red soft drinks represented $1.5 \%$ of all

3 soft drinks sold during this period.

Table 3 shows the results concerning the presence of colourants, the percentages of 5 colourants and the amounts in litres of the 17 studied beverages. Almost $48 \%$ of the red 6 beverages was made up by the red soft drinks, with one alone representing the $35.2 \%$ of the 7 market. Concerning the 15 red juice-based drinks, they ranged from a minimum of $0.17 \%$ to a 8 maximum of $11.96 \%$ of the market. Most of these were referred to as red orange juice (Fallico 9 et al., 2010), and, concerning their colour, in 7 this was due to the addition of anthocyanin 10 extracts, but in 8 it was due to the presence of Allura red. The colour of the two red soft 11 drinks was due to colourants: one contained a mixture of E122 and E110 and the other was 12 coloured with E129. The amount of colourants ranged from $10.86 \mathrm{mg} / \mathrm{l}$ in the first soft drink 13 (the sum of E122 and E110) to $55.91 \mathrm{mg} / \mathrm{l}$ in a juice-based drink (no. 14). It is interesting to 14 note that all but the soft drinks, which are usually perceived negatively, were very similar to 15 fruit juices. The contribution of actual fruit juices in these drinks to their colour is very small 16 or even sometimes negligible (Fallico et al., 2010). Instead, they have significant amounts of 17 colourants added, which are often quite higher than the amounts in soft drinks. The levels of 18 added colourants were very high in beverage nos. 5, 11 and 14, with $42.83,48.51$ and 55.91 $19 \mathrm{mg} / \mathrm{l}$ of E129, respectively. The first one claimed to have red orange juice properties whilst 20 the other two claimed to have strong antioxidant activity and berries. It is important to note 21 that consumption of the colourant depended on both its concentration in the beverages and on 22 beverage consumption rates. For instance, sample no. 17 represented the $35.2 \%$ of the market, 23 but it contributed $50.6 \%$ of Allura red consumption. Beverage nos. 11 and 14 each 24 represented each less than $3 \%$ of the market, but contributed to the $5.8 \%$ and $7.5 \%$ of Allura 25 red consumption, respectively. 
The average level of colourant in the red juice-based drinks was $29.6 \mathrm{mg} / \mathrm{l}$ and the

2 levels were lognormally distributed, while in the two soft drinks the average value was 20.5

$3 \mathrm{mg} / \mathrm{l}$ and the levels were normally distributed (Table 3).

In order to build a more realistic scenario to assess the daily intake of Red Allura from

red beverages, estimation of the number of consumers and a survey of these beverages was a

6 primary goal of this research. Literature data and the number of receipts were used to estimate

7 the total number of customers of the shopping centres. In turn, estimation for red drink

8 products consumers in one year was attempt.

Studies aimed to understand buyers' habits in Italy (Audipress, 2008; TNS, 2010)

highlighted that the majority of consumers, about the $75 \%$, prefer shopping chain.

11 Considering these as our population, their percentages as well as the frequency of purchases

12 are reported in Table 4. First, the total number of customers was divided in four categories, 13 considering the frequency of purchases. Than, considering that the number of receipts for 14 each category, is given by the number of customers multiplying the number of purchases, the 15 inverse formula (n. of receipts/n. of purchases) was used to estimate the number of customers 16 for each category. The number of receipts for each category was the result of a binomial 17 distribution of the total number of receipts and the related percentage. The total number of customers was given by adding the customers of all categories. The resulting number was 137370 as average, with a minimum value of 123648 and maximum of 153921 total customers. The best-fit distribution is a $\beta$-General one (Table 4).

From this, taking into account the tendency of customers to buy red beverages, the incidence of red products on the category and the number of consumers per buyer, were estimated the number of consumers for red beverages for the two scenarios $3 \mathrm{~A}$ and $3 \mathrm{~B}$, 24 respectively (Table 4). The two scenarios differ each other for the number of consumers per 25 buyer (or item). In fact, the scenario 3A hypotheses that each buyer is the consumer of the 
1 item, while the scenario 3B differs between the buyer and the numebr of consumers. In order

2 to build scenario 3B during two consecutive days in the largest of the 27 shopping centres, 30

3 buyers for each category of red beverages, juice based and soft drinks, were asked to say for

$4 \quad$ who and for how many people they were going to buy the red beverage. Regarding the red

5 juice based drinks they readily answered "for children" and the most common number of

6 consumers were one or two, up to three people per item. For this reason was chosen a

7 Triangular distribution $(1 ; 1.37 ; 3)$ centred on 1.37 (the average number of children per

8 female in Italy (ISTAT, 2010)) ranging between one and three. For soft drinks the most

9 common number of consumers declared per item was 3, ranging between 1 and 4. So, was 10 chosen a triangular distribution $(1 ; 3 ; 4)$.

11 For scenario 3A the average number of customers buying red soft drinks was 12 estimated to be 585, Log-normal distributed, ranging between 426 and 768 consumers (Table 13 4). While the average number of customers of red juice based drinks was 3571, Log-normal 14 distributed, ranging between 2586 and 4705. For scenario 3B it was estimated 1560 customers 15 for soft drinks, $\beta$-general distributed, ranging between 836 and 2360 customers. The estimated 16 number of juice based drinks consumers was 5009, Log-normal distributed, ranging between 173290 and 7210 customers. The sensitivity analysis highlighted that, in scenario 3A, the 18 uncertainty on the estimation of the number of customers was related to the tendency to buy 19 and to the incidence of the red products; while in scenario $3 \mathrm{~B}$ it was first related to the 20 number of consumers per buyer, followed by the two input described above (Table 4).

21 The yearly (litres) and daily (ml) consumptions of both red soft drinks and red juice22 based drinks were estimated (10000 iterations each) by dividing the litres sold for each 23 category by the appropriate customer distribution. These results are reported in Table 5. Both 24 consumption distributions were positively skewed, as found for other foods (Zhang et al., 25 2009). In fact, for both red soft drinks and red juice-based drinks the best fitting distribution 
1 was a lognormal one. Data suggest that, in scenario 3A, on average, a consumer drinks 53.1

2 litres of a red soft beverage per year. However, none of the values between 39.1 and 70.7

3 litres per year can be excluded (Table 5). This would mean a daily consumption of $145.4 \mathrm{ml}$

4 of red soft drinks, ranging between 107.1 and $193.8 \mathrm{ml}$. These data fully agree with literature,

5 both with the industrial and food consumption surveys. In fact, of the 65 litres of yearly

6 consumption per capita, 79\% (51.4 litres) must be ascribed to carbonated drinks (Bevitalia,

7 2010a), while the Italian food consumption survey reports a mean value of $130.9 \mathrm{ml}$ up to 330

$8 \mathrm{ml}\left(95^{\text {th }}\right.$ precentile) as daily consumption (Leclercq et al., 2009). Thus, the approach used here

9 to estimate the number of consumers of red beverages seemed to be appropriate. Moreover,

10 the consumption of red soft drinks only concerned a small fraction of the population;

11 however, this was at the same level as all of the other soft drinks. It seems that the 12 consumption of red soft drinks was not added to that of the other soft drinks, but rather it was 13 treated as an alternative to them. The yearly estimated consumption of red juice-based drinks, 14 for the same scenario, was 9.51 (25.6 ml/day), ranging between a minimum of $7.01(19.0$ $15 \mathrm{ml} /$ day) and a maximum of 12.51 (34.3 ml/day). The values reported here are similar to those 16 in Bevitalia (2010 b) (12.5 litres/year (34.6 ml/day)) for the category of nectars and juice 17 drinks; they are lower than those, reported as fruit and vegetable juices, found in the Italian 18 food consumption survey (64.4 $\mathrm{ml}$ up to $250 \mathrm{ml}$ at the $95^{\text {th }}$ percentile, Leclercq et al. 2009). 19 Lower values were estimated for scenario 3B (Table 5). In fact, the yearly estimated 20 consumption of red soft drinks ranged between 12.7 and 35.9 litres, with a most probable 21 value of 21.3 litres. It means a daily consumption of $58.3 \mathrm{ml}$ ranging between 34.8 and 98.4 $22 \mathrm{ml} /$ day. As concerns the estimation of consumption of red juice based products in scenario 3B 23 the results are the following: 6.9 litres/year (18.9 ml/day) ranging between 12.4 and 27.2 24 litres/year. The sensitivity analysis, analogously to the number of consumers estimation, have 25 shown that in scenario $3 \mathrm{~A}$ the main uncertainty factors are the tendency to buy and the 
1 incidence of the red beverages on the category, while in scenario $3 \mathrm{~B}$ these factors are

2 overcome by the number of consumers/buyer.

3 Combining the daily beverages consumption value with the concentration of the

4 colourant (Scenarios 1 and 2) or the distributions of E129 concentrations with those of 5 beverage consumption (Scenarios 3-4), the per capita estimation of yearly and daily intakes of 6 E129 were obtained (Tables 6-8). In the worst case (Scenario 1), considering a consumption 7 per capita of 64.4 and $130.9 \mathrm{ml} / \mathrm{d}$ on the average, 250 and $330 \mathrm{ml} / \mathrm{d}$ at the 95 th percentile, for 8 juice based and soft drinks (Leclercq et al., 2009), the average colorant intake was $6.5 \mathrm{mg} /$ day 9 and $13.0 \mathrm{mg} /$ day for juice-based and soft drinks, respectively. The daily intakes, for 10 consumers, at the $95^{\text {th }}$ percentile were 25.0 and $33 \mathrm{mg} /$ day for juice-based drinks and soft 11 drinks, respectively (Table 6). The second Scenario took in account the same consumption 12 rates of Scenario 1, but instead of the Maximum Permitted Level of the colorant (100 mg/l), 13 were used the average values found in these beverages (Table 3). Under these hyphoteses the 14 intake of colorant was 1.9 and $2.7 \mathrm{mg}$ /day from juice based and soft drinks, respectively. At 15 the $95^{\text {th }}$ percentile the intake was 7.4 and $6.8 \mathrm{mg} /$ day, respectively (Table 6).

16 These intakes, both for Scenario 1 and 2, according to categories of consumers 17 reported in Leclercq et al., (2009) (children (3-9.9 years), teenagers (10-17.9 years) and adults 18 (18-64.9 years)), were converted in $\mu \mathrm{g} \mathrm{kgbw}^{-1} \mathrm{day}^{-1}$ (Table 6). These data, analogusly to 19 literature (Tennant 2008, EFSA 2009, EXPOCHI 2010), highlighted that the most exposed 20 were children because of their high consume/body weight ratio. In fact, for Scenario 1, the 21 mean exposure values for red juice based and red soft drinks were 247.5 and $498.1 \mu \mathrm{g} \mathrm{kgbw}^{-}$ $22{ }^{1}$ day $^{-1}$, respectively. At the $95^{\text {th }}$ percentile the childrens' exposure was 957.9 and $1264.4 \mu \mathrm{g}$ $23 \mathrm{kgbw}^{-1} \mathrm{day}^{-1}$, respectively. The above data represent the $3.5 \%$ and the $7.1 \%$ on the mean, up to $2413.7 \%$ and $18.1 \%$ at the $95^{\text {th }}$ percentile of the A.D.I. value, for juice based and soft drinks, 25 respectively. Moreover, comparing the above data to those reported in the EXPOCHI (2010) 
1 study (M.P.L. scenario) concerning the total exposure to E129 of Italian Children, 773.7 and $26635.4 \mu \mathrm{g} \mathrm{kgbw}^{-1} \mathrm{day}^{-1}$ as mean value and at the $95^{\text {th }}$ percentile, respectively. They represent, 3 on the average the $32 \%$ up to the $64.4 \%$ of total intake for juice-based and soft drinks, 4 respectively. Lower values, $14.4 \%$ and $19.1 \%$ at the $95^{\text {th }}$ percentile.

Using the average levels of the colorant (Scenario 2) took to a much lower intake

(Table 6). In fact, under this scenario the daily intake per kilogram of body weight for Italian children was 73.2 and $102.3 \mu \mathrm{g}$ for juice-based and soft drinks, respectively. It could achieve 283.5 and $260.5 \mu \mathrm{g}$ at the $95^{\text {th }}$ percentile. Representing the 1.0 and $4.1 \%$ of the A.D.I. at mean and the $95^{\text {th }}$ percentile for juice-based drinks and 1.5 and $3.7 \%$ for soft drinks, respectively. The comparison with results of the "analytical scenario" reported in EXPOCHI (2010) study (524.3 and $1257.5 \mu \mathrm{g} \mathrm{kgbw}{ }^{-1} \mathrm{day}^{-1}$ as mean value and at $95^{\text {th }}$ percentile, respectively) highlights that the consumption of these beverages provides the $14.0 \%$ of colorant total daily intake (up to the $22.5 \%$ ) from juice-based drinks or the $19.5 \%$ (up to $20.7 \%$ ) for soft drinks.

The above scenarios took in account results of surveys not specific for red beverages and, scenario 1, using the maximum permitted level of the colorant. Moreover, these did not consider properly the amount of knowledge contained in the Input parameters in terms of uncertainty and the associated probability. Here follow the results of the E129 daily intake, using a probabilistic approach, in always more realistic scenarios (3A, 3B and 4) aimed to manage the uncertainty and variability about the number of consumers as well as the colorant level in the beverages.

Under the hypotheses of scenarios $3 \mathrm{~A}$ and $3 \mathrm{~B}$, using the distributions of: colorant levels, the year beverages intake and the appropriate number of consumers, dividing for 365 , was possible to get an estimation of the Red Allura daily intake (Table 6). Under scenario 3A it was $0.8 \mathrm{mg} / \mathrm{d}$, ranging between 0.2 and $1.7 \mathrm{mg} /$ day for juice-based drinks. The intake of E129 from red soft drinks was estimated to be $3.0 \mathrm{mg} /$ day, ranging between 0.4 and 5.9 
$1 \mathrm{mg} /$ day. The best fitting distribution for the daily intake was, in both cases, a lognormal one.

2 Under scenario 3B the daily intake from juice-based drinks was $0.6 \mathrm{mg}$ (range $0.2-1.3$

$3 \mathrm{mg} /$ day); it was $1.2 \mathrm{mg} /$ day from red soft drinks, ranging between 0.1 and $2.6 \mathrm{mg} /$ day.

The above data suggest that the intake $(\mu \mathrm{g})$ per children' kilogram of body weight

5 (Table 6) is $35.5 \mu \mathrm{g}$, ranging between 9.3 and $87.4 \mu \mathrm{g} \mathrm{kgw}^{-1} \mathrm{~d}^{-1}$, from juice-based drinks 6 under Scenario 3A and $29 \mu \mathrm{g}$, ranging between 6.6 and $67.7 \mu \mathrm{g} \mathrm{kgbw}^{-1} \mathrm{~d}^{-1}$, under Scenario 3B, 7 respectively. Representing, under the two scenarios, the $0.5 \%(0.1-1.3 \%)$ and the $0.4 \%(0.1-$ $8 \quad 1.0 \%$ ) of the A.D.I. value, respectively.

The daily intake of E129 from red soft drinks was $3.0 \mathrm{mg}$, ranging between 0.4 and 5.9 $\mathrm{mg} /$ day, under Scenario 3A, and $1.2 \mathrm{mg}$, ranging between 0.1 and $2.6 \mathrm{mg} / \mathrm{day}$, under Scenario 11 3B (Table 6). These mean $130.5 \mu \mathrm{g} \mathrm{kgbw}^{-1} \mathrm{~d}^{-1}\left(38.3-310.7 \mu \mathrm{g} \mathrm{kgbw}{ }^{-1} \mathrm{~d}^{-1}\right)$ under Scenario 3A 12 and $54.0 \mu \mathrm{g} \mathrm{kgbw}^{-1} \mathrm{~d}^{-1}\left(12.9-137.8 \mu \mathrm{g} \mathrm{kgbw}^{-1} \mathrm{~d}^{-1}\right)$ under Scenario 3B. Representing the 1.9\% $13(0.6-4.4 \%)$ and the $0.8 \%(0.2-2.0 \%)$ of the A.D.I. value, respectively.

14 The sensitivity analysis highlighted that most of the uncertainty in the estimation of 15 E129 daily intake in both scenarios was due to the variability of E129 level in red beverages, 16 followed by the tendency to buy and the market incidence for scenario 3A and the number of 17 consumers per buyer, the tendency to buy and the market incidence in scenario 3B, 18 respectively. The number of consumers per buyer becomes very meaningful in the estimation 19 of daily intake from soft drinks under scenario 3B (Table 6).

Although the intakes shown above can be considered as realistic since they were based 21 on both the true E129 concentration distribution and on red beverages consumption, they do 22 not provide information about brand loyalty behaviour. Moreover, this approach did not take 23 into account the contribution of each beverage to the E129 intake. For these reasons, an 24 estimation of E129 intake was made for each beverage and a weighted average were taken 25 (Scenario 4). Similar to other foods (Leclercq et al., 2003; Zhang et al., 2009), the market 
1 incidence, calculated using the percentage of litres (Table 3), and the number of consumers

2 found in scenario 3B, was used to estimate the per capita consumption of each beverage. The

3 E129 intake values were obtained for each beverage by dividing the $\mathrm{mg} /$ year of colourant

4 (Table 3) by the consumer distribution (Table 4), from which, in turn, the estimated daily 5 intake was obtained (Table 7).

A new average intake (Table 8), both for red juice-based and red soft drinks, was estimated using the following equation: $E D I=\sum\left(E D I_{i} * L_{i} / L_{T}\right)$. Where $\mathrm{EDI}_{\mathrm{i}}$ is the estimated daily intake for a single beverage, $\mathrm{L}_{\mathrm{i}}$ is the litres of the beverage and $\mathrm{L}_{\mathrm{T}}$ are the total litres for each category of juice-based and soft drinks. For the juice-based drinks (Table 7): three beverages $(11,14$ and 15$)$ showed a daily intake higher or equal to $1 \mathrm{mg} /$ day. For beverage 14, under the brand loyalty scenario, the intake of E129 achieved very high levels: $2.6 \mathrm{mg} /$ day (3.6 mg/day at the $95^{\text {th }}$ percentile). All other juice-based drinks containing E129 $(1,2,4,5$, 10) showed a daily intake equal or lower than $0.7 \mathrm{mg} / \mathrm{day}$. As mentioned above, beverage no. 5 claims to have red orange juice properties, whereas the other two, 11 and 14, claim to have very high antioxidant levels and healthy properties of berries. The EDI values for the two soft drinks (Table 7) were 0.2 and $0.5 \mathrm{mg} / \mathrm{day}$ with the highest values of 0.3 and $0.8 \mathrm{mg} / \mathrm{day}$, respectively. The weighted average daily intake for Allura red showed (Table 8) a lognormal distribution centred on $0.3 \mathrm{mg} /$ day for red juice-based drinks and $0.4 \mathrm{mg} / \mathrm{day}$ for red soft drinks. The highest values (95\% percentile) were 0.5 and $0.6 \mathrm{mg} /$ day, respectively. These data suggest a children intake of $14.7 \mu \mathrm{g} \mathrm{kg} \mathrm{bw} \mathrm{d}^{-1}\left(6.9-28.2 \mu \mathrm{g} \mathrm{kg} \mathrm{bw} \mathrm{d}^{-1}\right)$ from juice-based drinks and $19.8 \mu \mathrm{g} \mathrm{kg} \mathrm{bw}^{-1} \mathrm{~d}^{-1}\left(9.1-37.6 \mu \mathrm{g} \mathrm{kg} \mathrm{bw} \mathrm{d}^{-1}\right)$ from soft drinks, respectively. Representing the $0.2 \%(0.1-0.4 \%)$ of the A.D.I. value for juice-based drinks and the $0.3 \%$ $(0.1-0.5 \%)$ of the A.D.I. value for soft drinks, respectively. Under this scenario the uncertainty was due exclusively to the number of consumers.

The above data show that the estimation of the E129 daily intake changes significantly 
1 with the hypotheses under each scenario. There is a deep difference between the first scenario

2 and all others. In fact, under scenario 1 , the daily intake at the $95^{\text {th }}$ percentile of the colourant

3 from red soft drinks can achieve the $64 \%$ of the A.D.I. value for children. The more the

4 scenario becomes realistic the lower is the anticipated intake of E129, at least from red

5 beverages. In fact the anticipated daily intake from these beverages is always far from the 6 A.D.I. value.

$7 \quad$ The more refined becomes the scenario the lower is difference of the colourant intake 8 from juice-based and soft drinks, respectively: the colourant level in the beverages is the most 9 important factor affecting its daily intake. The loyalty to a single red beverage, if it has high 10 E129 levels, can significantly increase the daily intake of the colourant.

11 All of the beverages, with colourant concentrations below $30 \mathrm{mg} / \mathrm{l}$, did not show any 12 potential risk. Considering the findings reported in risk evaluation processes (EFSA, 2009), 13 these data clearly suggest that the main risk from the colourants in beverages may be from the 14 overall levels used. Although the risk assessment process did not call for a modification of the 15 allowed amounts of E129, the obligation of art. 24 of REG 1333/08 to include the additional 16 information "may have an adverse effect on activity and attention of children", can have, in 17 practice, the same effect as a ban on these products. A significant reduction in the amount of 18 E129 allowed in non-alcoholic beverages would help to protect young consumers. Moreover, 19 the data above highlight that if a risk does exist, it often comes from beverages claiming to 20 have healthy properties on their labels. Major restrictions from this point of view would be 21 very useful. 


\section{References}

2 Arcella D., Leclercq C. (2005). Assessment of dietary intake of flavouring substances within the procedure for their safety evaluation: advantages and limitations of estimates obtained by means of a per capita method. Food Chem. Toxicol. 43: 105-116.

Arena E., Campisi S., Fallico B., Maccarone E. (1998). Fatty acids of Italian blood orange juices. J. Agric. Food Chem 46: 4138-4143.

Arena E., Fallico B., Maccarone E. (2000). Influence of carotenoids and pulps on the color modification of blood orange juice. J. Food Science 65: 458-460.

Arena E., Fallico B., Maccarone E. (2001a). Thermal damage in blood orange juice: kinetics of 5-hydroxymethyl-2-furencarboxaldehyde formation. Int. J. of Food Science and Tech. 36: $145-151$.

Arena E., Fallico B., Maccarone E. (2001b). Evaluation of antioxidant capacity of blood orange juices as influenced by constituents, concentration process and storage. Food Chem. 74: 423-427.

Arena E., Guarrera N., Campisi S., Nicolosi Asmundo C. (2006). Comparison of odour active compounds detected by gas-chromatography olfactometry between hand-squeezed juices from different orange varieties. Food Chem. 8: 59-63.

Audipress (2008). Chi sono gli attuali “Responsabili Aquisti”. http://www.audipress.it/upload/intro\%20responsabili\%20aqcuisti\%202007_11.pdf. Pp $1-4$.

Bevitalia (2010a). Profilo del mercato italiano bibite analcoliche. A cura di Giada Giupponi. P. 19. In Bevitalia. Acque Minerali, Bibite e Succhi. Soft Drinks Directory 2010-2011. http://www.coffeeurope.eu/files/bevitalia.pdf. 
1 Bevitalia (2010b). Profilo del mercato italiano succhi e altre bevande naturali frutta. A cura di 2 Elisa Chirico. P. 24. In Bevitalia. Acque Minerali, Bibite e Succhi. Soft Drinks Directory 2010-2011. http://www.coffeeurope.eu/files/bevitalia.pdf.

Bitsch R., Netzel M., Frank T., Strass G., Bitsch I. (2004). Bioavailability and biokinetics of anthocyanins from red grape juice and red wine. J. of Biomed. and Biotech. 5: 293-298.

Bonina F.P., Puglia C., Cimino F., Trombetta D., Tringali G., Roccazzello A.M., Insirello E., Rapisarda P., Saija A. (2005). Oxidative stress in handball players: effect of supplementation with a red orange extract. Nutrition Research 25: 917-924.

Borzelleca J.F., Olson J.W., Reno F.E. (1989). Lifetime toxicity/carcinogenicity studies of FD\&C red 40 (Allura Red) in mice. Food Chem. Toxicol 27: 701-705.

Borzelleca J.F., Olson J.W., Reno F.E. (1991). Lifetime toxicity/carcinogenicity studies of FD\&C red 40 (Allura Red) in Sprague-Dawley rats. Food Chem. Toxicol 29: 313-319.

Bourrier T. (2006). Intolérances et allergies aux colourants et additifs. Revue française d'allergologie et d'immunologie clinique 46: 68-79.

Di Mauro A., Fallico B., Passerini A., Maccarone E. (2000). Waste water from citrus processing as source of hesperidin by concentration on styrene-divinylbenzene resin. $\mathrm{J}$. Agric. Food Chem 48: 2291-2295.

Di Mauro A., Arena E., Fallico B., Passerini A., Maccarone E. (2002). Recovery of anthocyanins from pulp wash of pigmented oranges by concentration on resins. J. Agric. Food Chem 50: 5968-5974.

Directive 2008/128/EC of 22 December 2008. Laying down specific purity criteria concerning colours for use in food stuffs (L 6/20 of 10.01.2009).

Douglass J.S., Tennant D.R. (1997). Estimation of dietary intake of food chemicals. In Chapman \& Hall (Ed.), Food Chemical Risk Analysis, London. pp. 212-215. 
1 European Food Safety Authority. (2008). Assessment of the results of the study by McCann et

al. (2007) on the effect of some colours and sodium benzoate on children's behaviour. The EFSA Journal 660: 1-54.

European Food Safety Authority. (2009). Scientific opinion on the re-evaluation of Allura Red AC (E129) as a food additive. The EFSA Journal 7 (11) 1327: 1-39.

EXPOCHI (2010). Long-term dietary exposure to different food colours in young children living in different European contries. Pp 1-70. http://www.efsa.europa.eu/it/supporting/pub/53e.htm.

Fallico B., Lanza M.C., Maccarone E., Nicolosi Asmundo C., Rapisarda P. (1996). Role of Hydroxycinnamic acids and vinylphenols in the flavor alteration of blood orange juices. J. Agric. Food Chem 44: 2654-2657.

Fallico B., D'Urso MG., Chiappara E. (2009). Exposure to pesticides residues from consumption of Italian blood oranges. Food Additiv. and Cont. (Part A - Chemistry Analysis Control Exposure \& Risk Assessment 26: 1024-1032.

Fallico B., Chiappara E., Arena E., Ballistreri G. (2010). Evaluation of color contribution and label conformity of pasteurized red juices and related drinks. Food Additiv.and Contam. (Part B - Surveillance). 3: 201-211.

Feingold B.F. (1975). Why is your child hyperactive? New York: Random House

Galvano F., La Fauci L., Lazzarino G., Fogliano V., Ritieni A., Ciappellano S., Battistini N.C., Tavazzi B., Galvano G. (2004). Cyanidins: metabolism and biological properties. Journal of Nutritional Biochemistry 15: 2-11.

Ginsberg G., Hattis D., Miller R., Sonawane B. (2004). Pediatric pharmacokinetic data: implications for environmental risk assessment for children. Pediatrics 113: 973-983.

Giovenali A. (2008). "Per sete o per semplice piacere. Largo Consumo n. 7/8: 93-96. 
1 Hattis D., Goble R., Russ A., Chu M., Ericson J. (2004). Age-related differences in

2

3

4 5 susceptibility to carcinogenesis: a quantitative analysis of empirical animal bioassay data. Environmental Health Perspectives 112: 1152-1158.

Husain A., Sawaya W., Al-Omair A., Al-Zenki S., Al-Amiri H., Ahmed N., Al-Sinan M. (2006). Estimates of dietary exposure of children to artificial food colours in Kuwait. Food Additiv. and Contam. 23(3): 245-251.

ISTAT 2010. Numero medio figli per donna. http://demo.istat.it/altridati/indicatori/2010/Tab_4.pdf

JECFA. (1974). FAS 6/NMRS 54A-JECFA 18. Toxicological evaluation of some food colours, enzymes, flavour enhancers, thickening agents, and certain other food additives. FAO Nutrition Meetings Report Series, No. 54A, 1975; WHO Food Additives Series, No. 6, 1975.

JECFA. (1980). TRS 653-JECFA 24. Evaluation of certain food additives (Twenty-fourth report of the Joint FAO/WHO Expert Committee on Food Additives). WHO Technical Report Series, No. 653, 1980.

JECFA. (1981). FAS 16-JECFA 25. Toxicological evaluation of certain food additives. WHO Food Additives Series, No. 16, 1981.

Leclercq C., Arcella D., Le Donne C., Piccinelli R., Sette S., Soggiu M.E. (2003). Stochastic modelling of human exposure to food chemicals and nutrients within the "Montecarlo" project. An exploration of the influence of brand loyalty and market share on intake estimates of intense sweeteners from sugar-free soft drinks. Toxicology Letters 140-141: 443-457.

Leclercq C., Arcella D., Piccinelli R., Sette S., Le Donne C., Turrini A. (2009). The Italian National Food Consumption Survay INRAN-SCAI 2005-06: main results in terms of food consumption. Public Health Nutrition 12 (12): 2504-2532. 
1 Maccarone E., Maccarrone A., Rapisarda P. (1983). Antocyanins of the Moro orange juice.

2

3 Annali di Chimica 73: 533-539.

Maccarone E., Maccarrone A., Rapisarda P. (1985). Acylated anthocyanins from oranges. Annali di Chimica 75: 79-86.

Maccarone E., Campisi S., Fallico B., Rapisarda P., Sgarlata R. (1998). Flavor components of Italian orange juices. J. Agric. Food Chem 46: 2293-2298.

Mazza G. (2007). Anthocyanins and heart health. Ann. Ist Super Sanità 43 (4): 369-374.

McCann D., Barrett A., Cooper A., Crumpler D., Dalen L., Grimshaw K., Kitchin E., Lok K., Porteous L., Prince E., Sonuga-Barke E., O Warner J., Stevenson J. (2007). Food additives and hyperactive behaviour in 3-year-old and 8/9 year-old children in the community: a randomised, double-blinded, placebo-controlled trial. Lancet 370: 156067.

Minioti K.S., Sakellariou C., Thomaidis N.S. (2007). Determination of 13 synthetic food colourants in water-soluble foods by reversed-phase high performance liquid chromatography coupled with diode array detector. Analyt. Chim. Acta 583: 103-110.

Muraca P., (2007) Il succo della competizione. Largo Consumo 9: 31-36.

Petersen B.J., Barraj J.L.M. (1996). Assessing the intake of contaminants and nutrients: an overview of methods. J. Food Comp. Anal. 9: 243-254.

Rao P., Bhat R.V., Sudershan R.V., Krishna T.P., Naidu N. (2004). Exposure assessment to synthetic food colours of a selected population in Hyderabad, India. Food Additiv. and Contam. 21(5):415-421.

Rapisarda P., Carollo G., Fallico B., Tomaselli F., Maccarone E. (1998). Hydroxycinnamic acids as markers of Italian blood orange juices. J. Agric. Food Chem. 46: 464-470.

Reed N.R. (1997). Assessing risks to infants and children. In Tennant D.R (Ed.), Food Chemical Risk Analysis. Blackie Academic \& Professional, London .pp. 219-239. 
1 Regulation (EC) No. 1333/2008 of the European Parliament and of the Council of 16

2 December 2008 on food additives. Official Journal of the European Union 31.12.2008, L354/16.

4 Report from the Commission on Dietary Food Additives Intake in the European Union, 2001 http://ec.europa.eu/food/fs/sfp/addit_flavor/flav15_en.pdf last accessed 10 Jan 2010.

6 Rossi M. (2006). Successo alla frutta. Largo Consumo 5: 91-95.

7 Sasaki Y.F., Kawaguchi S., Kamaya A., Ohshita M., Kabasawa K., Iwama K., Taniguchi K., Tsuda S. (2002). The comet assay with 8 mouse organs: results with 39 currently used food additives. Mutation Research 519: 103-119.

SCF (1975). Reports of the Scientific Committee for Food ( $1^{\text {st }}$ series $)$, opinion expressed on 31 December 1975. http://ec.europa.eu/food/fs/sc/scf/reports/scf_reports_01.pdf

SCF (1984). Reports of the Scientific Committee for Food (14 ${ }^{\text {th }}$ series), opinion expressed on 7 July 1983. http://ec.europa.eu/food/fs/sc/scf/reports/scf_reports_14.pdf.

SCF (1989). Reports of the Scientific Committee for Food (21 ${ }^{\text {th }}$ series), opinion expressed on 10 December 1987. http://ec.europa.eu/food/fs/sc/scf/reports/scf_reports_21.pdf.

Serota D.G., Voelker R.W., Reno F.E., Tiede J.J. (1977) In JECFA 1980. Lifetime carcinogenic study in the albino rat. Unpublished report number 165-149 by Hazelton Laboratories America INC.

Slob W., Pieters M.N. (1998). A probabilistic approach for deriving acceptable human intake limits and human health risks from toxicological studies: general framework. Risk Analysis 18: 787-798.

Slob W. (2006) Probabilistic dietary exposure assessment taking into account variability in both amount and frequency of consumption. Food and Chem. Toxicol. 44: 933-951. 
1 Spanjersberg M.Q.I., Kruizinga A.G., Rennen M.A.J., Houben G.F. (2007). Risk assessment

2

3 and food allergy: the probabilistic model applied to allergens. Food and Chem. Toxicol. 45: 49-54.

Tennant D.R. (2008). Screening potential intakes of colour additives used in non-alcoholic beverages. Food and Chem. Toxicol. 46: 1985-1993.

TNS Italia (2010). Lo shopping journey: attitudini e comportamenti in fase d'acquisto. Milano, 12 ottobre 2010. $4^{\wedge}$ Consumer \& Retail Summit. http://www.pwc.com/it/it/industries/retail-consumer/docs/rc-shopping-journey.pdf.

Tsuda S., Murakami M., Matsusaka N., Kano K., Taniguchi K., Sasaki Y.F. (2001) DNA damage induced by red food dyes orally administered to pregnant and make mice. Toxicol. Sci. 61, 92-99.

Vorhees C.V., Butcher R.E., Brunner R.L., Wootten V., Sobotka T.J. (1983). Developmental toxicity and psychotoxicity of FD \& C red dye No 40 (Allura Red AC) in rats. Toxicology 28: 207-217.

Vose D.J (2000) Risk Analysis. A quantitative guide. Second edition. John Wiley \& Sons, Ltd., England.

Weir R.J. (1965a). In JECFA 1980. Acute oral administration - rats, five experimental nontoxic red colors. Unpublished report $165-114$ by Hazelton Laboratories Inc. Submitted by Allied Chemical Company.

Weir R.J. (1965b). In JECFA 1980. Acute oral administration - dogs, five experimental nontoxic red colors. Unpublished report $165-114$ by Hazelton Laboratories Inc. Submitted by Allied Chemical Company.

Weir R.J. (1967). In JECFA 1980. Acute dermal administration - rabbits, Re d Z-4576. Unpublished report $165-119$ by Hazelton Laboratories Inc. Submitted by Allied Chemical Company. 
1 WHO Food Additives Series 15. Allura Red AC (2009).

2 http://www.inchem.org/documents/jecfa/jecmono/v15je02.htm last accessed 10 Jan 32010.

4 Wu X., Beecher G.R., Holden J.M., Haytoitz D.B., Gebhardt S.E., Prior R.L. (2006). 5 Concentrations of anthocyanins in common foods in the United States and Estimation of 6 normal consumption. J. Agric. Food Chem 54: 4069-4075.

7 Zhang Y., Nakai S., Masunaga S. (2009). An exposure assessment of methyl mercury via fish 8 consumption for the Japanese population. Risk Analysis 29: 1281-1291. 
Table 1 - Description of Input used for the models.

\begin{tabular}{|c|c|c|c|}
\hline & Method & Input & References \\
\hline 1 & $\begin{array}{l}\text { Maximum } \\
\text { Permitted Level } \\
\text { (M.P.L.). }\end{array}$ & $\begin{array}{l}\text { - Consumption of fruit juices, ml/day: 130.9; } 330 \text { (mean; 95th). } \\
\text { - Consumption of Soft drinks, ml/day: 64.4; } 250 \text { (mean; 95th). } \\
\text { - Maximum Concentration allowed of E129 in beverages: } 100 \text { mg/l. }\end{array}$ & $\begin{array}{l}\text { - The Italian National Food Consumption } \\
\text { Survey 2005-06 (Leclercq et al., 2009). } \\
\text { - Annex II, REG. EC 1333/08 (L 354/16). }\end{array}$ \\
\hline 2 & $\begin{array}{l}\text { Single Point } \\
\text { Method (S.P.M.) }\end{array}$ & $\begin{array}{l}\text { - Consumption of fruit juices, ml/day: 130.9; } 330 \text { (mean; 95th). } \\
\text { - Mean concentration of E129 in juice based drinks: Table } 3 \text {. } \\
\text { - Consumption of Soft drinks ml/day: 64.4; } 250 \text { (mean; 95th). } \\
\text { - Mean concentration of E129 in soft drinks: Table 3. }\end{array}$ & $\begin{array}{l}\text { - The Italian National Food Consumption } \\
\text { Survey 2005-06 (Leclercq et al., 2009). }\end{array}$ \\
\hline $3 A$ & Probabilistic & 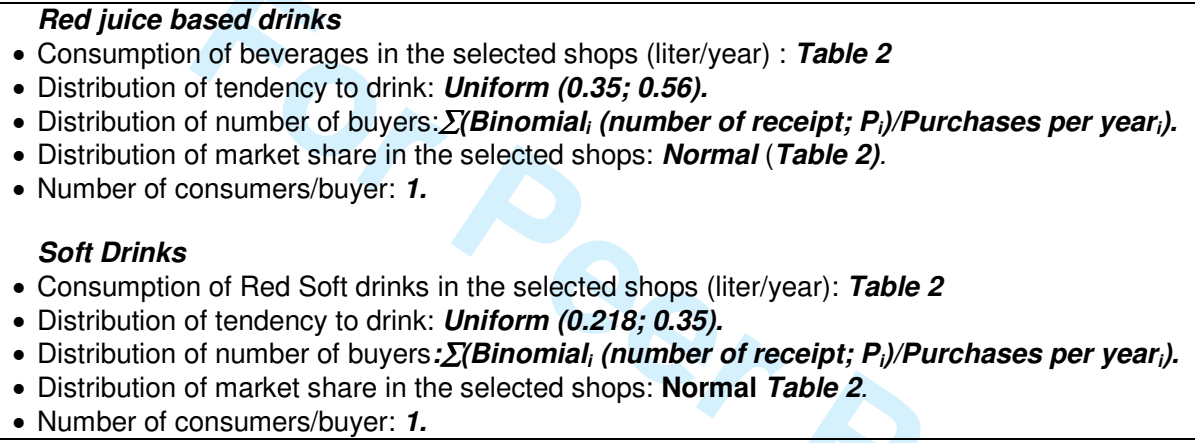 & $\begin{array}{l}\text { • Audipress, } 2008 . \\
\text { • Bevitalia, } 2010 \text { a,b. } \\
\text { • Giovenali, } 2008 . \\
\text { - The Italian National Food Consumption } \\
\text { Survey 2005-06 (Leclercq et al., 2009). } \\
\text { - Arcella and Leclercq 2005. }\end{array}$ \\
\hline $3 B$ & Probabilistic & 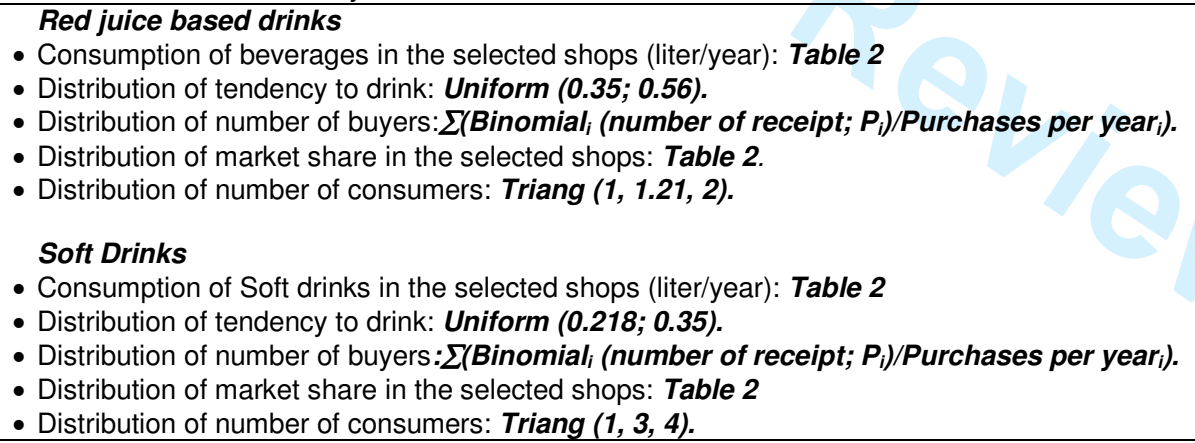 & $\begin{array}{l}\text { • Audipress, } 2008 . \\
\text { - Bevitalia, } 2010 \text { a,b. } \\
\text { • Giovenali, } 2008 . \\
\text { • ISTAT, } 2010 . \\
\text { - The Italian National Food Consumption } \\
\text { Survey 2005-06 (Leclercq et al., 2009). } \\
\text { - Arcella and Leclercq 2005. }\end{array}$ \\
\hline 4 & Probabilistic & $\begin{array}{l}\text { Red juice based drinks } \\
\text { - Consumption of each red fruit based beverages (liters/year). } \\
\text { - Distribution of number of consumers: Scenario 3B. } \\
\text { Soft Drinks } \\
\text { - Consumption of each soft drink in the selected shops (liters/year). } \\
\text { - Distribution of number of consumers: Scenario 3B. }\end{array}$ & - Leclercq et al., 2003. \\
\hline
\end{tabular}


Table 2 - Data from the shooping centers.

\begin{tabular}{|l|l|}
\hline No. Of shopping centers & 27 \\
\hline No. Of receipts & 5100630 \\
\hline No. Of items per year (red beverages) & 49856 \\
\hline Litres per year (red beverages) & 62682.8 \\
\hline Litres per year (red juice based) & 32640.8 \\
\hline Litres per year (red soft drinks) & 30042 \\
\hline Incidence of red soft drink & $1.5 \%$ \\
\hline Incidence of red juice based dirnks & $5.7 \%$ \\
\hline
\end{tabular}

Table 3 - Market incidence and colorant data of each beverage.

\begin{tabular}{|c|c|c|c|c|c|c|c|c|c|}
\hline \multirow{2}{*}{ Beverage no. } & \multirow[b]{2}{*}{ Drinks } & \multicolumn{3}{|c|}{ Litres per year } & \multicolumn{5}{|c|}{ Colourants } \\
\hline & & Litres & $\%$ on Total & $\%$ on Category & Colourant & mg/l (st. dev.) & mg/year (st .dev.) & $\%$ on Total & $\%$ on Category \\
\hline 1 & \multirow{15}{*}{ Juice based } & 4774 & 7.62 & 14.63 & E 129 & $29.30(0.52)$ & $139878.2(2482.4)$ & 10.6 & 25.00 \\
\hline 2 & & 1043 & 1.66 & 3.20 & E 129 & $23.76(1.06)$ & $24781.7(1105.5)$ & 1.9 & 4.00 \\
\hline 3 & & 2536 & 4.05 & 7.77 & No Colourants & & & & \\
\hline 4 & & 7497 & 11.96 & 22.97 & E 129 & $16.71(0.36)$ & $125274.9(2699.0)$ & 9.5 & 22.00 \\
\hline 5 & & 862 & 1.38 & 2.64 & E 129 & $42.83(1.79)$ & $36919.5(1543.1)$ & 2.8 & 7.00 \\
\hline 6 & & 4966 & 7.92 & 15.21 & No Colourants & & & & \\
\hline 7 & & 729.75 & 1.16 & 2.24 & No Colourants & & & & \\
\hline 8 & & 594 & 0.95 & 1.82 & No Colourants & & & & \\
\hline 9 & & 786.75 & 1.26 & 2.41 & No Colourants & & & & \\
\hline 10 & & 1647.75 & 2.63 & 5.05 & E 129 & $16.03(0.22)$ & $26413.4(362.5)$ & 2.0 & 5.00 \\
\hline 11 & & 1586.25 & 2.53 & 4.86 & E 129 & $48.51(2.44)$ & $76949.0(3870.4)$ & 5.8 & 14.00 \\
\hline 12 & & 109.5 & 0.17 & 0.34 & No Colourants & & & & \\
\hline 13 & & 1803 & 2.88 & 5.52 & No Colourants & & & & \\
\hline 14 & & 1759.8 & 2.81 & 5.39 & E 129 & $55.91(0.44)$ & $98390.4(774.4)$ & 7.5 & 17.00 \\
\hline \multirow[t]{2}{*}{15} & & 1946 & 3.10 & 5.96 & E 129 & $17.93(1.58)$ & $34891.8(3074.8)$ & 2.6 & 6.00 \\
\hline & & & \multicolumn{6}{|c|}{ LogNormal $(29.6 ; 18.1)$} & \\
\hline 16 & \multirow{2}{*}{ Soft } & 7977 & 12.73 & 27.00 & $\mathrm{E} 122+\mathrm{E} 110$ & $10.86(1.80)$ & $86630.2(4360)$ & 6.6 & 11.00 \\
\hline 17 & & 22065 & 35.20 & 73.00 & E 129 & $30.22(1.49)$ & $666804.3(32876)$ & 50.6 & 89.00 \\
\hline
\end{tabular}


Table 4-Estimated number of red beverages per year.

\begin{tabular}{|c|c|c|c|c|c|c|}
\hline \multirow{7}{*}{ 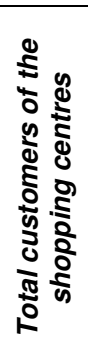 } & \multirow{6}{*}{$\stackrel{5}{s}$} & Frequency of purchases & $\%$ & Purchases per year & \multicolumn{2}{|l|}{ Number of customers } \\
\hline & & Never & 25 & - & \multirow{2}{*}{\multicolumn{2}{|c|}{ Binomial $(5100630 ; 0.131) / 12$}} \\
\hline & & 1 per month & 13.1 & 12 & & \\
\hline & & 2-3 per month & 23.6 & Uniform $(24 ; 36)$ & \multicolumn{2}{|c|}{ Binomial $(5100630 ; 0.236) /$ Uniform $(24 ; 36)$} \\
\hline & & 4-8 per month & 52.8 & Uniform $(48 ; 96)$ & \multicolumn{2}{|c|}{ Binomial $(5100630 ; 0.528 /$ /Uniform $(48 ; 96)$} \\
\hline & & $>21$ per month (daily) & 10.5 & 252 & \multicolumn{2}{|c|}{ Binomial $(5100630 ; 0.105) / 252$} \\
\hline & $\frac{5}{5}$ & Total customers & & \multicolumn{3}{|c|}{$\begin{array}{c}\text { Mean: 137370; st.dev.:9212; } \min (5 \%): \text { 123648; } \operatorname{Max}(95 \%): 153921 \\
\quad \beta \text {-General (1.99; 3.2; 119333; 166273); K-S: } 0.01\end{array}$} \\
\hline & & & & & & \\
\hline \multirow{6}{*}{ 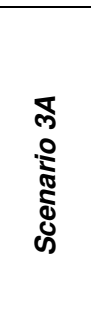 } & \multirow{5}{*}{$\stackrel{5}{5}$} & Total Customers & & \multicolumn{3}{|c|}{$\beta$-General $(1.99 ; 3.2 ; 119333 ; 166273)$} \\
\hline & & $=$ & 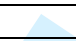 & \multirow{2}{*}{\multicolumn{2}{|c|}{$\begin{array}{c}\text { Red Soft } \\
\text { Uniform }(0.218: 0.35)\end{array}$}} & Red Juice based \\
\hline & & Tendency to buy & $(\mathrm{c}$ & \multirow{2}{*}{\multicolumn{2}{|c|}{$\begin{array}{l}\text { Uniform }(0.218 ; 0.35) \\
\text { Normal }(0.015 ; 0.0015)\end{array}$}} & Uniform $(0.35 ; 0.562)$ \\
\hline & & Incidence on category & & & & Normal $(0.057 ; 0.0057)$ \\
\hline & & Number of consumers per buyer & & \multicolumn{2}{|c|}{1} & 1 \\
\hline & $\frac{\mathfrak{2}}{5}$ & $\begin{array}{l}\text { Number of consumers } \\
\text { (Uncertainty (rank and regr.)) }\end{array}$ & & \multicolumn{2}{|c|}{$\begin{array}{c}\text { Mean: 585; st. dev.: 106; } \min (5 \%) \text { : } 426 ; \text { Max (95\%): } 768 \\
\text { LogNormal (585; 106); K-S: } 0.0173 \\
\text { (1. tendency to buy: } 0.74 ; 2 . \text { Incidence \%: } 0.55) .\end{array}$} & $\begin{array}{c}\text { Mean: 3571; st. dev.: 654; } \min (5 \%): 2586 ; \operatorname{Max}(95 \%): 4705 \\
\text { LogNormal (3571; 654); K-S: } 0.013 \\
\text { (1. tendency to buy: } 0.74 ; 2 . \text { Incidence \%: } 0.55)\end{array}$ \\
\hline & & & & & & \\
\hline \multirow{6}{*}{ 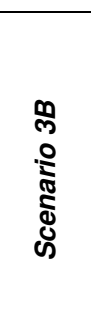 } & \multirow{5}{*}{$\stackrel{5}{\Xi}$} & Total Customers & & \multicolumn{3}{|c|}{$\beta$-General $(1.99 ; 3.2 ; 119333 ; 166273)$} \\
\hline & & & & \multirow{2}{*}{\multicolumn{2}{|c|}{\begin{tabular}{|c|} 
Red Soft \\
Uniform $(0.218 ; 0.35)$
\end{tabular}}} & Red Juice based \\
\hline & & Tendency to buy & & & & Uniform $(0.35 ; 0.562)$ \\
\hline & & Incidence on category & & \multicolumn{2}{|c|}{ Normal $(0.015 ; 0.0015)$} & Normal $(0.057 ; 0.0057)$ \\
\hline & & Number of consumers per buyer & & \multicolumn{2}{|c|}{ Triang $(1 ; 3 ; 4)$} & Triang $(1 ; 1.21 ; 2)$ \\
\hline & $\frac{5}{5}$ & $\begin{array}{l}\text { Number of consumers } \\
\text { (Uncertainty (rank and regr.)) }\end{array}$ & & \multicolumn{2}{|c|}{$\begin{array}{l}\text { Mean: 1560; st. dev.: 465; } \min (5 \%) \text { : 836; } \operatorname{Max}(95 \%): 2360 \\
\quad \beta \text {-General (4.9; 9.4; 252; 4080); K-S: } 0.0074\end{array}$} & $\begin{array}{l}\text { Mean: 5009; st. dev.: 1194; } \min (5 \%) \text { : 3290; } \operatorname{Max}(95 \%): 7210 \\
\text { LogNormal (5009; 1194); } \text { K-S: } 0.0075\end{array}$ \\
\hline
\end{tabular}


Table 5 - Estimation of yearly and daily consumption of red beverages.

\begin{tabular}{|c|c|c|c|c|c|}
\hline & & Red soft drinks & Uncertainty (rank and regr.) & Red juice based & Uncertainty (rank and regr.) \\
\hline \multirow{10}{*}{ 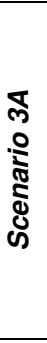 } & & Yearly (litres) & \multirow{10}{*}{$\begin{array}{l}\text { 1) tendency to buy: }-0.73 \\
\text { 2) Incidence \%: - } 0.55\end{array}$} & Yearly (litres) & \multirow{10}{*}{$\begin{array}{l}\text { 1) tendency to buy: }-0.73 \\
\text { 2) Incidence \%: - } 0.55\end{array}$} \\
\hline & Mean (St. dev.): & $53.1(9.8)$ & & $9.5(1.8)$ & \\
\hline & Min (5\%): & 39.1 & & 7.0 & \\
\hline & $\operatorname{Max}(95 \%):$ & 70.7 & & 12.5 & \\
\hline & Best fit: & LogNormal $(53.1 ; 9.8) ; \mathrm{K}-\mathrm{S}: 0.0154$ & & LogNormal $(9.5 ; 1.8) ; \mathrm{K}-\mathrm{S}: 0.0185$ & \\
\hline & & Daily (milliliters) & & Daily (milliliters) & \\
\hline & Mean (St. dev.): & $145.4(27)$ & & $25.6(4.8)$ & \\
\hline & $\operatorname{Min}(5 \%):$ & 107.1 & & 19.0 & \\
\hline & Max (95\%): & +9 & & 34.3 & \\
\hline & Best fit: & LogNormal $(145.4 ; 27) ; \mathrm{K}-\mathrm{S}: 0.0154$ & & LogNormal $(25.6 ; 4.8) ; \mathrm{K}-\mathrm{S}: 0.0185$ & \\
\hline \multirow{10}{*}{ 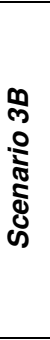 } & & Yearly (litres) & \multirow{10}{*}{$\begin{array}{l}\text { 1) n. of consumers: }-0.79 \\
\text { 2) tendency to buy: }-0.38 \\
\text { 3) Incidence } \%:-0.30\end{array}$} & Yearly (litres) & \multirow{10}{*}{$\begin{array}{l}\text { 1) n. of consumers: }-0.61 \\
\text { 2) tendency to buy: }-0.58 \\
\text { 3) Incidence \%: }-0.43\end{array}$} \\
\hline & Mean (St. dev.): & $21.3(7.4)$ & & $6.9(1.6)$ & \\
\hline & $\operatorname{Min}(5 \%)$ & 12.7 & & 3.2 & \\
\hline & $\operatorname{Max}(95 \%):$ & 35.9 & & 17.7 & \\
\hline & Best fit: & LogNormal $(21.3 ; 7.4) ; \mathrm{K}-\mathrm{S}: 0.0082$ & & LogNormal $(6.9 ; 1.6) ; \mathrm{K}-\mathrm{S}: 0.0071$ & \\
\hline & & Daily (milliliters) & & Daily (milliliters) & \\
\hline & Mean (St. dev.): & $58.3(20.4)$ & & $18.9(4.5)$ & \\
\hline & Min (5\%): & 34.8 & & 12.4 & \\
\hline & $\operatorname{Max}(95 \%):$ & 98.4 & & 27.2 & \\
\hline & Best fit: & LogNormal $(58.3 ; 20.4) ; \mathrm{K}-\mathrm{S}: 0.0082$ & & LogNormal $(18.9 ; 4.5) ; \mathrm{K}-\mathrm{S}: 0.0071$ & \\
\hline
\end{tabular}


Table 6 - Estimation of E129 Daily Intake from red beverages.

\begin{tabular}{|c|c|c|c|c|c|}
\hline \multirow{2}{*}{ Scenario 1} & Intake (mg/d) & \multicolumn{3}{|c|}{ Intake $(\mu \mathrm{g} / \mathrm{d} / \mathrm{kg} \mathrm{bw})$} & \multirow[t]{2}{*}{ Uncertainty (rank and regr.) } \\
\hline & & $3-9.9$ years & $10-17.9$ years & 18-64.9 years & \\
\hline \multirow{2}{*}{ Red juice based } & \multirow{2}{*}{$\begin{array}{l}\text { Intake }_{\text {av. }}=0.0644 * 100=6.4 \\
\text { Intake } 95 \text { th }=0.250 * 100=25.0\end{array}$} & 247.5 & 122.8 & 92.7 & \\
\hline & & 957.9 & 475.3 & 358.7 & \\
\hline \multirow{2}{*}{ Red soft } & \multirow{2}{*}{$\begin{array}{l}\text { Intake } \text { av. }=0.131 * 100=13.1 \\
\text { Intake } 95 \text { th }=0.330 * 100=33.0\end{array}$} & 498.1 & 247.1 & 186.5 & \\
\hline & & 1264.4 & 627.4 & 473.5 & \\
\hline \multicolumn{5}{|l|}{ Scenario 2} & \\
\hline \multirow{2}{*}{ Red juice based } & \multirow{4}{*}{$\begin{array}{l}\text { Intake }{ }_{\text {av. }}=0.0644 * 29.6=1.9 \\
\text { Intake }_{95 \text { th }}=0.250 * 29.6=7.4 \\
\text { Intake } \\
\text { Intake }_{95 \text { th }}=0.131 * 20.530 * 20.5=6.8\end{array}$} & 73.2 & 36.3 & 27.4 & \\
\hline & & 283.5 & 140.7 & 106.2 & \\
\hline \multirow{2}{*}{ Red soft } & & 102.3 & 50.8 & 38.3 & \\
\hline & & 260.5 & 129.3 & 97.6 & \\
\hline \multirow{2}{*}{\multicolumn{2}{|c|}{ 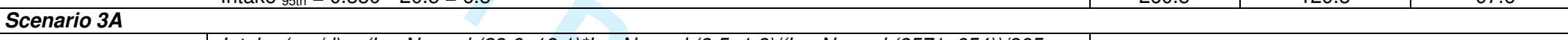 }} & & & & \\
\hline \multirow{4}{*}{ Red juice based } & Intake $(\mathrm{mg} / \mathrm{d})=\left(\operatorname{LogNormal}(29.6 ; 18.1)^{*} \operatorname{LogNormal}(9.5,1.8) /(\operatorname{LogNormal}(3571 ; 654)) / 365\right.$ & & & & \\
\hline & \multirow{3}{*}{$\begin{array}{l}\text { Intake }{ }_{\text {av. }}=0.8(0.5) \\
\text { Intake } 5 \text { th }=0.2 \\
\text { Intake }_{95 \text { th }}=1.7\end{array}$} & $35.5(64.7)$ & $16.3(12.3)$ & $12.0(8.0)$ & \multirow{3}{*}{$\begin{array}{l}\text { 1) } \mathrm{mg} / \mathrm{l} \text { of E129: } 0.94 \\
\text { 2) tendency to buy: }-0.213 \\
\text { 3) incidence \%: }-0.157\end{array}$} \\
\hline & & 9.3 & 4.8 & 3.7 & \\
\hline & & 87.4 & 37.5 & 26.9 & \\
\hline \multirow{4}{*}{ Red soft } & Intake $(\mathrm{mg} / \mathrm{d})=\left(\operatorname{LogNormal}(20.5 ; 10.8)^{*} \operatorname{LogNormal}(53.1,9.8) / \operatorname{LogNormal}(585 ; 106)\right) / 365$ & & & & \\
\hline & Intake ${ }_{\text {av. }}=3.0(1.7)$ & $130.5(304.4)$ & $61.2(42.4)$ & $44.9(28.2)$ & \multirow{3}{*}{$\begin{array}{l}\text { 1) } \mathrm{mg} / \mathrm{l} \text { of } \mathrm{E} 129: 0.935 \\
\text { 2) tendency to buy: }-0.24 \\
\text { 3) incidence } \%:-0.181\end{array}$} \\
\hline & Intake ${ }_{5 \text { th }}=0.4$ & 38.3 & 19.7 & 15.0 & \\
\hline & Intake 95 th $=5.9$ & 310.7 & 135.1 & 97.7 & \\
\hline \multicolumn{6}{|l|}{ Scenario 3B } \\
\hline \multirow{4}{*}{ Red juice based } & \multicolumn{4}{|l|}{ Intake $(\mathrm{mg} / \mathrm{d})=\left(\right.$ LogNormal $(29.6 ; 18.1)^{*}$ LogNormal $(6.9,1.6) /$ LogNormal $\left.(5009 ; 1194)\right) / 365$} & \multirow{4}{*}{$\begin{array}{l}\text { 1) } \mathrm{mg} / \mathrm{l} \text { of } \mathrm{E} 129: 0.91 \\
\text { 2) } \mathrm{n} \text {. of consumers: }-0.215 \\
\text { 3) tendency to buy: }-0.202 \\
\text { 4) Incidence \%: }-0.149\end{array}$} \\
\hline & \multirow{3}{*}{$\begin{array}{l}\text { Intake }_{\text {av. }}=0.6(0.4) \\
\text { Intake }_{5 \text { th }}=0.2 \\
\text { Intake }_{95 \text { th }}=1.3\end{array}$} & $29.1(262.3)$ & $12.2(9.5)$ & $9.0(6.5)$ & \\
\hline & & 6.6 & 3.4 & 2.5 & \\
\hline & & 67.7 & 29.0 & 21.1 & \\
\hline \multirow{4}{*}{ Red soft } & Intake $(\mathrm{mg} / \mathrm{d})=\left(\right.$ LogNormal $(20.5 ; 10.8)^{*}$ LogNormal $(21.3,7.4) /$ LogNormal $\left.(1560 ; 465)\right) / 365$ & & & & \multirow{4}{*}{$\begin{array}{l}\text { 1) } \mathrm{mg} / \mathrm{l} \text { of } \mathrm{E} 129: 0.81 \\
\text { 2) } \mathrm{n} \text {. of consumers: }-0.417 \\
\text { 3) tendency to buy: }-0.202 \\
\text { 4) Incidence \%: }-0.161\end{array}$} \\
\hline & Intake $_{\mathrm{av} .}=1.2(0.8)$ & $54.0(100.8)$ & $24.5(20.6)$ & $17.9(12.7)$ & \\
\hline & Intake ${ }_{5 \text { th }}=0.1$ & 12.9 & 6.7 & 5.1 & \\
\hline & Intake $_{95 \text { th }}=2.6$ & 137.8 & 58.1 & 41.8 & \\
\hline
\end{tabular}


Table 7 - Estimation of E129 daily intake from single red beverage.

\begin{tabular}{|c|c|c|c|c|}
\hline & $\%$ Litres & $\%$ Colourants & Consumers & Daily intake (mg) \\
\hline \multicolumn{5}{|l|}{1} \\
\hline Min. (5\%) & & & 484 & 0.36 \\
\hline Max. (95\%) & & & 1050 & 0.79 \\
\hline Mean (St. dev.) & 14.6 & 24.8 & $733(175)$ & $0.55(0.13)$ \\
\hline Best fit & & & $\log N(484 ; 175)$ & $\log N(0.55 ; 0.13)$ \\
\hline \multicolumn{5}{|l|}{2} \\
\hline Min. (5\%) & & & 106 & 0.29 \\
\hline Max. (95\%) & & & 229 & 0.65 \\
\hline Mean (St. dev.) & 3.2 & 4.4 & $160(38)$ & $0.45(0.11)$ \\
\hline Best fit & & & $\log N(160 ; 38)$ & $\log N(0.45 ; 0.11)$ \\
\hline 4 & - & & & \\
\hline Min. (5\%) & & & 759 & 0.21 \\
\hline Max. (95\%) & & & 1649 & 0.45 \\
\hline Mean (St. dev.) & 23.0 & 22.1 & $1150(275)$ & $0.32(0.08)$ \\
\hline Best fit & & & $\log N(1150 ; 275)$ & $\log N(0.32 ; 0.08)$ \\
\hline 5 & & L & & \\
\hline Min. (5\%) & & & 87 & 0.53 \\
\hline Max. (95\%) & & & 190 & 1.03 \\
\hline Mean (St. dev.) & 2.6 & 6.6 & $132(32)$ & $0.74(0.20)$ \\
\hline Best fit & & & $\log N(132 ; 32)$ & $\log N(0.74 ; 0.20)$ \\
\hline \multicolumn{5}{|l|}{10} \\
\hline Min. (5\%) & & & 167 & 0.20 \\
\hline Max. (95\%) & & & 362 & 0.43 \\
\hline Mean (St. dev.) & 5.1 & 4.7 & $253(60)$ & $0.30(0.07)$ \\
\hline Best fit & & & $\log N(253 ; 60)$ & $\log N(0.30 ; 0.07)$ \\
\hline 11 & & & 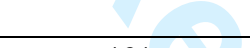 & \\
\hline Min. (5\%) & & & 161 & 0.60 \\
\hline Max. (95\%) & & & 349 & 1.32 \\
\hline Mean (St. dev.) & 4.9 & 13.7 & $243(58)$ & $0.92(0.22)$ \\
\hline Best fit & & & $\log N(243 ; 58)$ & $\log N(0.92 ; 0.22)$ \\
\hline \multicolumn{5}{|l|}{14} \\
\hline Min. (5\%) & & & 178 & 1.85 \\
\hline Max. (95\%) & & & 387 & 3.59 \\
\hline Mean (St. dev.) & 5.4 & 17.5 & $270(65)$ & $2.58(0.55)$ \\
\hline Best fit & & & $\log N(270 ; 65)$ & $\log N(1.55,0.55 ;$ shift 1.02$)$ \\
\hline \multicolumn{5}{|l|}{15} \\
\hline Min. (5\%) & & & 83 & 0.70 \\
\hline Max. (95\%) & & & 161 & 1.52 \\
\hline Mean (St. dev.) & 6.0 & 6.2 & $121(24)$ & $1.06(0.25)$ \\
\hline Best fit & & & $\log N(121 ; 24)$ & $\log N(1.06 ; 0.25)$ \\
\hline \multicolumn{5}{|l|}{16} \\
\hline Min. (5\%) & & & 878 & 0.11 \\
\hline Max. (95\%) & & & 1906 & 0.29 \\
\hline Mean (St. dev.) & 26.6 & 11.5 & $1330(318)$ & $0.19(0.06)$ \\
\hline Best fit & & & $\log N(1330 ; 318)$ & $\log N(0.19 ; 0.06)$ \\
\hline \multicolumn{5}{|l|}{17} \\
\hline Min. (5\%) & & & 2428 & 0.34 \\
\hline Max. (95\%) & & & 5272 & 0.76 \\
\hline Mean (St. dev.) & 73.4 & 88.5 & 3679 (879) & $0.52(0.13)$ \\
\hline Best fit & & & $\log N(3679 ; 879)$ & $\log N(0.52 ; 0.13)$ \\
\hline
\end{tabular}

Uncertainty: $N$. of consumers (regr.> - 0.90) 
Table 8 - Weighted estimation of E129 daily intake from red beverages (scenario 4).

\begin{tabular}{|c|c|c|c|c|}
\hline \multirow{2}{*}{\multicolumn{2}{|c|}{ Intake (mg/d) }} & \multicolumn{3}{|c|}{ Intake $(\mu \mathrm{g} / \mathrm{d} / \mathrm{kg}$ bw) } \\
\hline & & \multirow[t]{2}{*}{$3-9.9$ years } & \multirow[t]{2}{*}{ 10-17.9 years } & \multirow[t]{2}{*}{ 18-64.9 years } \\
\hline & juices based drinks & & & \\
\hline Mean (St. dev.) & $0.34(0.09)$ & $14.7(34.9)$ & $6.7(2.8)$ & $4.9(1.7)$ \\
\hline Min. (5\%) & 0.22 & 6.9 & 3.7 & 2.8 \\
\hline Max. $(95 \%)$ & 0.50 & 28.2 & 11.7 & 8.0 \\
\hline Best fit & LogNormal $(0.34 ; 0.09) \mathrm{K}-\mathrm{S}: 0.007$ & & & \\
\hline \multicolumn{2}{|r|}{ Red soft drinks } & & & \\
\hline Mean (St. dev.) & $0.44(0.11)$ & $19.8(53.3)$ & $9.0(5.2)$ & $6.6(2.3)$ \\
\hline Min. (5\%) & 0.28 & 9.1 & 4.8 & 3.8 \\
\hline Max. $(95 \%)$ & 20 & 37.6 & 15.3 & 10.7 \\
\hline Best fit & LogNormal $(0.44 ; 0.11) ; \mathrm{K}-\mathrm{S}: 0.003$ & & & \\
\hline
\end{tabular}

Uncertainty: $N$. of consumers (regr.> - 0.9). 